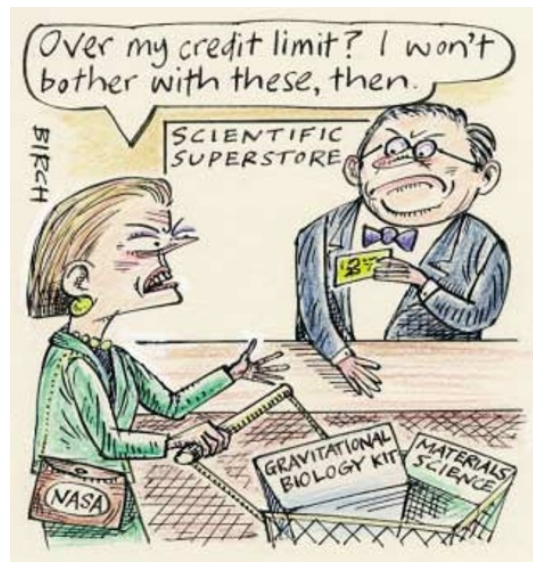

rankled with some space biologists, who point to studies questioning the value of past biotechnology experiments in space (see Nature 404, 114; 2000).

If NASA must choose between disciplines to make financial ends meet, it should first establish "what is the mission of the station", says Milburn Jessup, a surgeon at the University of Texas Health Science Center in San Antonio, who chairs NASA's station utilization subcommittee. Before the workshop is held to outline research priorities, the agency should decide which of two broad thrusts is the more important - a long-term presence in space, including human missions to the Moon and Mars, or research on improving products and processes on Earth.

Such a choice may be necessary if Congress decides not to give NASA the extra $\$ 4$ billion $-\$ 5$ billion the agency says it needs over the next five years to complete the station - this is on top of the $\$ 8$ billion already budgeted. Early signs are that lawmakers are so exasperated with the agency's poor control over costs that they may withhold the money as a disciplinary measure. In a recent report accompanying the NASA spending bill for 2002, the Senate appropriation subcommittee that oversees the agency's budget said in unusually blunt terms: "The Committee has lost confidence in the [station] programme's ability to responsibly manage the budget."

But Baldwin concludes that more money for the rescue vehicle and other hardware is "the only solution we see" that would ensure that the station is an efficient multidisciplinary laboratory. Martin Fettman, who chairs NASA's oversight panel for some of the lab equipment marked for cancellation, says his committee "has come close" to resigning in protest over the proposed cuts. Although scrapping equipment such as the animal holding facility is "unacceptable", he says, scientists might be willing to support stretching out the timeline for installing such equipment on the station. But until NASA comes back with an amended plan, he says, "we're out in the vapour, waiting".

\title{
Johns Hopkins embroiled in fresh misconduct allegations
}

\section{K. S. Jayaraman, New Delhi}

A researcher from Johns Hopkins University in Baltimore is among those accused of unethical conduct in a clinical trial carried out in India. The scandal has emerged barely a week after clinical trials at Johns Hopkins University were temporarily suspended following the death of a volunteer in a drug trial (see Nature 412, 363; 2001).

The high court in the state of Kerala has accepted a petition claiming that an investigational drug was injected into cancer patients at the Regional Cancer Centre (RCC) in Thiruvananthapuram, the state capital, without clearance from the Drug Controller General of India, and without approval from the institutional ethical committee.

The chief minister of Kerala, Arakkal Parambil Kurien Antony, last week ordered an investigation into the clinical trial.

The drug in question is $\mathrm{M} 4 \mathrm{~N}$, a derivative of the natural product nordihydroguaiaretic acid (NGDA), which has been used as a herbal remedy but is known to cause liver and kidney damage. Krishnan Nair, RCC director and principal investigator of the clinical trial, confirmed that the drug was injected into tumours of 27 patients awaiting surgery between November 1999 and April 2000. Clearance from the Drugs Controller was first received in 2001. Ganga Devi, convener of the ethical committee, said that approval was given in November 1999 for topical drug administration but not for injection.

But Nair told Nature that he had "verbal" permission from the Drug Controller General and written consent from patients. He said he thought that the drug was non-toxic, on the basis of studies in mice conducted at Johns Hopkins, which had also indicated that it was effective against virusinduced cancers in mice.

$\mathrm{Ru}$ Chih C. Huang, a professor of biology at Johns Hopkins, supplied the drug, which his team had developed as part of an antiHIV research programme. He also initiated and funded the Indian trial. Although details of the agreement have been kept secret, sources said that the RCC undertook this work for a fee of US $\$ 750,000$. Huang did not respond to requests from Nature for an interview.

Nair said that his US collaborators would be flying to India next week to respond to the allegations.

Narayanan Bhattathiri, associate professor of radiotherapy at RCC, blew the whistle on the trial. Although he is also head of the clinical radiobiology section, he says: "Curi- ously we were not informed about the trial."

Bhattathiri informed the Human Rights Committee, a body established by the Indian parliament, that "what was done in the name of clinical research is very surprising". Each patient was given three injections into one area of their tumour. The tumour was surgically removed after three or four days for microscopic examination of the injected region. "It is clear that the injection was done not with the aim of producing any tumour regression," says Bhattathiri, "but to see how long the chemical stays in the injected spot and to evaluate its effect at a microscopic level."

Three patients whose tumours could not be removed were given radiation therapy, despite the fact that "no one knows the interaction between radiation and this drug," Bhattathiri says. "Such conduct in clinical trials will make Kerala and India an animal house."

But Nair said that he is happy with the outcome of the trials, claiming that the tumour in one patient disappeared three days after the injection. In a press statement on 28 February he claimed joint credit with John Hopkins University in announcing that the drug had been effective in treating certain virus-induced cancers.

But Bhattathiri says that the only role the RCC played in the development of the drug was to provide unsuspecting patients, who believed they were being treated with the latest therapy from the United States.

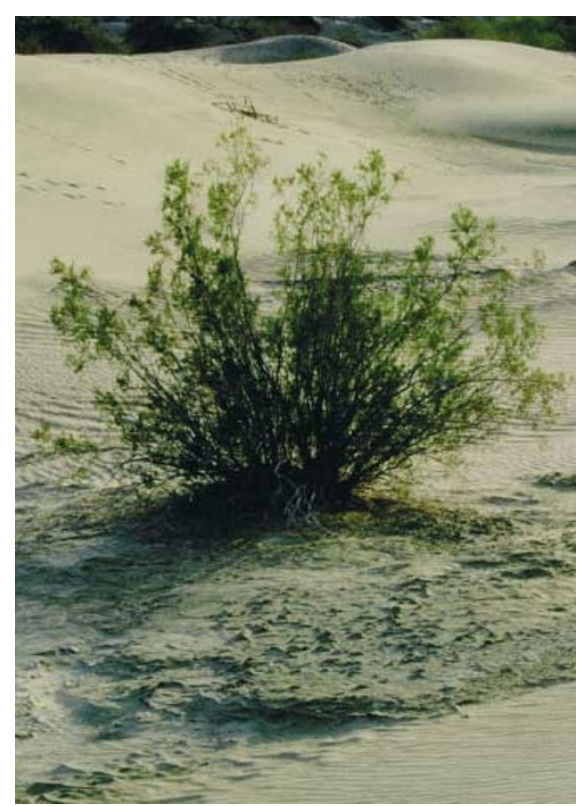

Trials of M4N, a drug derived from the creosote bush (Larrea tridentatia), have raised concerns. 